\title{
Research
}

\section{Building ties: social capital network analysis of a forest community in a biosphere reserve in Chiapas, Mexico}

\author{
$\underline{\text { Luis Rico García-Amado }}{ }^{1}$, Manuel Ruiz Pérez $^{2}, \underline{\text { Irene Iniesta-Arandia }}^{1}, \underline{\text { Guillaume Dahringer }}^{3}$, Felipe Reyes $^{4}$, and \\ Sara Barrasa $^{5}$
}

\begin{abstract}
Governance of the commons depends on the capacity to generate collective action. Networks and rules that foster that collective action have been defined as social capital. However, their causal link is still not fully understood. We use social network analysis to assess social capital, decision-making, and collective action in a forest-based common pool resource management in La Sepultura Biosphere Reserve (Chiapas, Mexico). Our research analyzes the productive networks and the evolution of coffee groups in one community. The network shows some centrality, with richer landholders tending to occupy core positions and poorer landless peasants occupying peripheral ones. This has fostered the community's environmentally oriented development but has also caused internal conflicts. Market requirements have shaped different but complementary productive networks, where organic coffee commercialization is the main source of bridging ties, which has resulted in more connectivity and resilience. Conservation attitudes, along with the institutional setting of the community, have promoted collective action. The unresolved conflicts, however, still leave some concerns about governance in the future.
\end{abstract}

Key Words: collective action; community forest management; ejido; Mexico; social capital; social network analysis

\section{INTRODUCTION}

Conservation and development initiatives in tropical forests rely on the governance of ecosystems (Folke et al. 2005). Governance varies according to the types of natural resources, property rights, and institutions ruling them (Schlager and Ostrom 1992, Vatn 2007). The importance and tradition of communal forests in the tropics (Richards 1997, Gilmour and Fisher 2011) has led to proposing common pool resource management as a viable approach to achieve forest conservation and development (Klooster and Masera 2000, Berkes 2004, Charnley and Poe 2007).

Within the broad literature on the governance of the commons (Feeny et al. 1990, Ostrom 1990, Agrawal 2001, Dietz et al. 2003), collective action is a sine qua non condition for a sustainable use of common pool resources (Ostrom 1990, Pretty and Smith 2004). However, the way in which collective action is produced is still not fully understood (Heckathorn 1996, Agrawal and Ostrom 2001), and some doubts and concerns have been expressed in relation to community forest management (Acheson 2006, Tacconi 2007, Ezzine de Blas et al. 2011).

The concept of social capital has gained support in the literature as a means for fostering collective action by lowering transaction costs and inhibiting free-riding (Ostrom 1994, Putnam 2001, Lehtonen 2004). Based on the idea of social embeddedness (Granovetter 1973), social capital has been defined as "the norms and networks facilitating collective action for mutual benefit" (Woolcock 1998:155). Among these norms and networks, relations of trust; reciprocity and exchanges; common rules, norms, and sanctions; and connectedness in networks and groups are positively related to collective action for a sustainable governance of the commons (Pretty and Ward 2001).

The social capital concept has been criticized for its lack of clarity (Portes 2000, Portes and Landolt 2000). The causality link between social capital and collective action can be tautological (Ballet et al. 2007). Some critics argue that norms and networks are not enough to explain the success in conservation without including other factors, such as cultural background (Cleaver 2000, Ballet et al. 2007). On the other hand, social capital, despite achieving positive environmental outcomes, can have negative impacts for poorer and marginalized populations (Agarwal 2001, Van Staveren 2003). Thus, it can obscure class and power relations (Harriss 2002).

Ishihara and Pascual (2009) integrate these criticisms, proposing Chwe's (1999) concept of "common knowledge" to fill the gap between social capital, collective action, and natural resource governance. Common knowledge is the set of understandings embedded in a given social structure, which enables putting resources to a particular use. Consequently, social capital generates a common knowledge that, depending on the power relationships, can be shared in order to succeed in collective action (Ishihara and Pascual 2009).

Social network analysis (SNA) provides the tools for understanding embeddedness and power structures within any group, and thereby helps to unravel the links between social capital and collective action in natural resource management (Gould 1993, Borgatti and Foster 2003, Siegel 2009, Bodin

\footnotetext{
${ }^{1}$ Ecology Department. Universidad Autónoma de Madrid, ${ }^{2}$ Ecology Department. Universidad Autónoma de Madrid., ${ }^{3}$ Pronatura-Sur A.C., ${ }^{4}$ Universidad de Ciencias y Artes de Chiapas, ${ }^{5}$ Colegio de Michoacán
} 
and Prell 2011). SNA also illustrates the existence of subgroups in network structures, which complements the understanding of intra-community power relations and possible specializations around livelihood activities (Girvan and Newman 2002).

We analyze the social network ( $\mathrm{SN}$ ) of a forest community to understand social capital, decision-making, and collective action in forest-based common pool resource management. Despite some case studies (Crona and Bodin 2006, Ernstson et al. 2008, Prell et al. 2008, Downey 2010), social networks fieldwork research on natural resource management is still limited (Bodin and Crona 2009, Crona and Hubacek 2010). With this study we attempt to contribute to the social network research on bottom-up approaches to govern the commons. Specifically, we analyze the social relations around the management of a common pool resource and try to establish the role of social networks in productive activities and in achieving a common knowledge aimed at conserving the forests upon which these activities rely.

\section{Community forestry in Mexico}

Mexico is a laboratory for community tenure (Bray et al. 2005). The main common property type is the ejido, a structure created after the 1910 revolution in order to give land to poor peasants. Ejidos are held communally and involve community work, "tequio", even though de facto they often mix communal land and private property (Haenn 2006). In 1992 the Constitution was changed in order to legalize the parceling of the ejido (Cornelius and Myhre 1998, Klooster 2003). Currently, 54\% of Mexican land corresponds to ejidos, of which about $2 / 3$ is still used communally (INEGI 2007). Of the total 31,500 communities, between 7000 and 9000 live in or nearby forests (Bray et al. 2005, INEGI 2007).

There are two types of dwellers inside ejidos. Ejidatarios own the land and have full rights in the community's assembly, where decisions about the management of common land are taken. Pobladores have no land tenure rights-except for small pieces of land sold or donated by ejidatarios - and do not vote in the assembly; therefore, although they can participate in some common land management activities, they do not take part in the decision-making process. Inheriting is the main way to become an ejidatario, a factor that hinders land acquisition and the access to full land entitlement for the new generations (Barnes 2009). The tension between ejidatario and poblador tends to underscore the rest of social relations in the ejido.

Mexico has a long tradition of forest resource management (Toledo et al. 2003). Examples of it can be found in coffee agroforests in the Mexican south (Moguel and Toledo 1999) or in community managed forests in Quintana Roo, Oaxaca, Durango, or Guerrero (Wilshusen et al. 2002, Bray et al. 2005). Based on these experiences, Mexico has developed policies for fostering community development by combining primary (agriculture, forestry), secondary (small-scale rural industries), and tertiary (ecotourism) activities (Torres 2003, Bray et al. 2006).

\section{Study area}

The study was conducted in the ejido Sierra Morena, located in La Sepultura Biosphere Reserve, Chiapas, Mexico. The ejido has 1750 ha of a variety of ecosystems - mixed pineoak, cloud, and subperennial rainforest-due to an altitudinal variation that goes from 750 to 1400 meters above sea level. In 1970 a group of landless farmers took the land from a big landowner who was illegally holding it, a very common story in the area because Chiapas did not benefit from land reform right after the revolution (Bobrow-Strain 2004). The first ejidatarios had to defend the land from the illegal landowner's attacks until the ejido was formally established in 1978. During that time, the community decided to work the land collectively, until internal problems led to the parceling of the 340 ha of productive land in 1981, while the rest remained collectively managed.

Poor results after the initial planting of the traditional beans and corn system "milpa" led to a shift towards a more environmental approach based on shade coffee and Chamaedorea palm so as "not to cut down all the forest", as different founders of the ejido told us. Since the creation of the biosphere reserve in 1995, governmental and nongovernmental environmental institutions have underpinned the conservation strategies of the ejido, reinforcing palm and coffee while promoting ecotourism and introducing a Payment for Environmental Services (PES) scheme. That has turned conservation into the "hallmark" of the place, as all the dwellers agree on the important benefits of conserving the forest (Rico García-Amado et al. 2011).

Thirty-two households permanently live in the ejido, seven of which are pobladores. Coffee is the main cash-generating activity, representing $50 \%$ of total income; palm is second, representing almost $25 \%$. PES, other social subsidies, cattle ranching, and ecotourism constitute the rest. Non market activities - production of corn, beans, chickens, and backyard vegetables-are marginal, although they represent an important part of the pobladore's income.

\section{METHODS}

A total of six months of participant observation took place at different times from 2007 to 2009, which allowed time to win interviewees confidence and to corroborate ex-post the results of the analysis. Semi-structured interviews of all adults in the ejido $(n=66)$ were implemented at different times to gather socioeconomic and management information. The social network survey was conducted during January and February 2010 and included all household heads $(n=32)$, the network thus representing the ejido's dwellers' universe. Women were included in the socioeconomic questionnaires but did not take part in the SNA because their collaboration in the main cash- 
generating activities is very limited and they do not participate in the assemblies. This was confirmed by the fact that no woman was mentioned as part of the social relations network in the social network interviews.

The SNA focused on two main topics: the analysis of the different groups established in productive activities, and the temporal analysis of the coffee groups in the area. The latter was selected due to the economic importance of coffee and the fact that it has showed a strong dynamism with several partitions and restructurings during the last decade.

The first topic was covered by a single question: "To whom do you relate for different productive activities?"- "relate" referring to work-related demand of assistance. Each interviewee was asked to establish their list of interactions. The fact that "A" mentioned "B" does not necessarily imply that "B" mentioned "A". This resulted in a directional, binary, actor-by-actor matrix. Responses were codified according to the different activities mentioned, resulting in an ejido's global network, which could be divided into five specific networks: coffee, palm, ecotourism, authorities, and general all-purpose.

Coffee group data for the second topic of the network analysis were obtained during the interviews by asking stakeholders about the coffee groups they had belonged to in the past. These data were cross-checked with the environmental organizations that were working in the area and collaborating with coffee groups. After the detailed social network survey of 2010, the coffee groups changed again, and this information was updated based on specific data requested for this purpose.

Data analysis was done using UCINET 6.0 (network analysis), NetDraw 2.098 (graph visualization), and two statistical packages: SPSS 17.0 and R. Because standard inferential statistical tools cannot be applied to SNA, we used a random permutation approach to test differences in the attributes that explain network centrality (Hanneman and Riddle 2005).

\section{RESULTS}

\section{Productive network analysis}

The sociogram of all the relationships identified during the interviews is shown in Figure 1. We used UCINET categorical core/periphery genetic algorithm to calculate the degree of resemblance of the data to a star network $(0=$ no resemblance; $1=$ perfect resemblance), and obtained a fitness of 0.524 . The block density matrix of the categorical core/periphery analysis gave values of 0.625 for core-core ties and 0.058 for peripheryperiphery ties, suggesting a non-negligible level of centrality (Hanneman and Riddle 2005).

Network betweenness was $31.71 \%$, indicating a tendency to form groups (Bodin et al. 2006). Clustering and groups were analyzed using NetDraw. Girvan-Newman clustering best fit $(\mathrm{Q}=0.158)$ consisted of five groups: three single peripheral nodes; a five-nodes group, clearly separated on the right part of Figure 1; and a large group with the remaining 24 nodes. The five-nodes group, which as shown below has specific features, was also identified in a two-groups clustering based on either factions or geodesic distances, which validates the identification of this specific group. However, this group was not isolated due to the existence of bridging links with some core members.

Fig. 1. Sociogram based on all relationships. Node size is proportional to cash income.

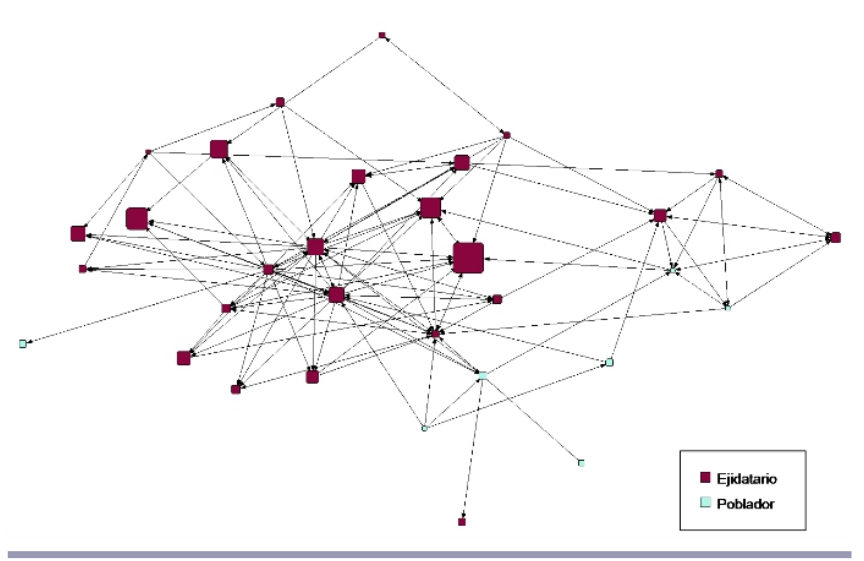

Indegree quantifies how much a given person is a reference or focal point for the rest, which indicates the ability of an individual to be relied on, and thus creates a hierarchical network with the most sought after individuals at the top. Outdegree goes from a given actor to the rest of the ejido, which measures the capacity of connecting with others. The hierarchy of the network was assessed using Krackhardt GTD analysis (Krackhardt 1994). Three of the four parameters were close to 1 (connectedness $=1.000$; hierarchy $=0.554$; efficiency $=0.841$; least upper bound $=0.983$ ), indicating the presence of a hierarchy in the network.

The two main factors determining the position in the network were land tenure and level of income, two variables that are covariates (U Mann-Whitney; $z=3.305 ; p=0.001$ ). The core was occupied by richer ejidatarios, whereas the poorer pobladores were displaced towards the periphery. Moreover, income and tenure affected particularly the indegree, whereas they did not have a significant effect on the outdegree, as showed in Figure 2. Indegree-based $T$-test for tenure confirmed that ejidatarios were mentioned significantly more often $(t=1.891 ; p=0.034)$, but there were no statistical differences in outdegree $(t=0.458 ; p=0.325)$. Likewise, the ANOVA test for levels of income indicated that the upper income tercile had a significantly higher indegree $(F=4.007$; $p=0.029)$, whereas no significant differences were found regarding outdegree $(F=0.041 ; p=0.928)$. Age and education had no significant effect on degree of centrality. 
Table 1. Characteristics of the specific networks; n.s.= not statistically significant.

\begin{tabular}{|c|c|c|c|c|c|c|c|}
\hline & $\begin{array}{l}\text { Active } \\
\text { Nodes }\end{array}$ & Ties & Transitivity & $\begin{array}{c}\text { Network } \\
\text { Central. } \\
\text { Indegree }\end{array}$ & $\begin{array}{l}\text { Network Central. } \\
\text { Outdegree }\end{array}$ & $\begin{array}{l}\text { Tenure status (Fisher } \\
\text { test, bilateral) }\end{array}$ & $\begin{array}{c}\text { Income } 2010 \\
\text { (Fisher Freeman } \\
\text { Halton) }\end{array}$ \\
\hline General & 28 & 51 & $7.76 \%$ & 11.34 & 14.67 & n.s. & n.s. \\
\hline Coffee & 20 & 22 & $2.20 \%$ & 11.03 & 17.69 & n.s. & $\begin{array}{l}\text { High Income } \\
(p=0.054)\end{array}$ \\
\hline Palm & 19 & 54 & $11.86 \%$ & 11.03 & 50.99 & $\begin{array}{c}\text { Ejidatario } \\
(p=0.091)\end{array}$ & $\begin{array}{l}\text { High Income } \\
(p=0.000)\end{array}$ \\
\hline Ecotourism & 4 & 6 & $25.00 \%$ & 6.04 & 9.37 & n.s. & $\begin{array}{l}\text { Low Income } \\
(p=0.097)\end{array}$ \\
\hline Authorities & 12 & 11 & $0.00 \%$ & 32.15 & 5.52 & n.s. & n.s. \\
\hline
\end{tabular}

Fig. 2. Outdegree and indegree boxplots for (a) land tenure (ejidatario versus poblador) and (b) income group (terciles of income).

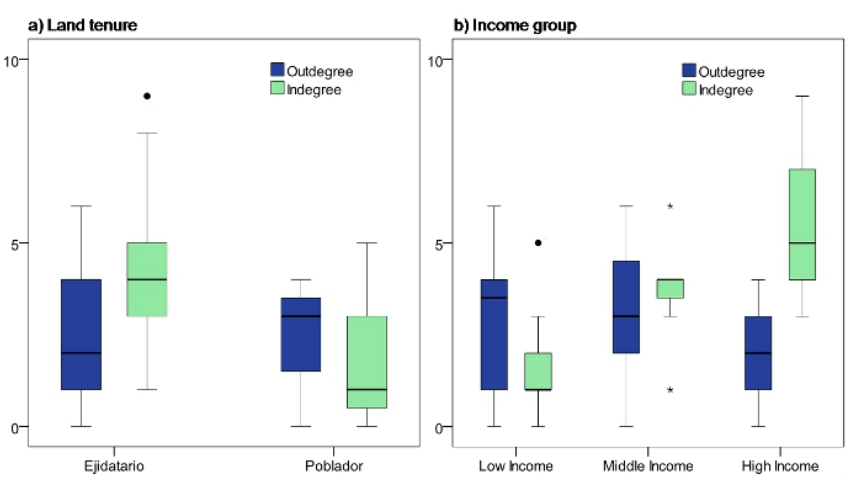

The global network included five types of relationships: three specific economic activities (coffee, palm, and ecotourism); a general, all-purpose, economic-related link; and the interactions with the formal, publicly elected authorities of the ejido. This resulted in five networks that could occasionally have overlapping bonds, such as coffee and palm. However, this overlapping was infrequent, as the global network had 123 ties, whereas the specific networks ties summed 144 altogether. The characteristics of the specific networks are summarized in Table 1.

The general network, constructed on all-purpose or unspecified relations, included most of the ejido's members. Coffee, the main economic activity carried out by all members of the community, was the largest of the three income-related networks. The palm network was also large (despite this activity being less spread out) because it involves all members of the palm cooperative and had the highest number of ties. The ecotourism network was composed of the four people engaged in this activity who do not belong to the palm cooperative. The authorities network had the highest indegree and resembled an almost pure star network because the Comisariado ejidal attracted all the bonds.
The degree of closeness of each specific network was estimated through its transitivity - the probability that if " $\mathrm{A}$ " directs a tie to "B" and "B" directs a tie to " $C$ ", then "A" also directs a tie to "C" (Girvan and Newman 2002, Hanneman and Riddle 2005). Ecotourism and palm had the highest transitivity, which suggested tied, cohesive groupings, although care must be taken, especially in the case of the ecotourism network due to its small size.

We applied Fisher's small samples exact test between ejidatarios and pobladores to compare their participation in the different networks (Table 1). Ejidatarios were significantly more present on the palm network, whereas pobladores did not take part more significantly in any of the networks. We used the Freeman-Halton extension of Fisher's exact test for more than two populations to contrast income terciles. People from the high income tercile were more present in the coffee and palm networks, while the ecotourism network was made mostly of people in the lower income tercile. The general and authorities networks did not show significant differences in their parameters with regards to tenure or income.

Individuals were assigned to the specific network for which they had the highest indegree, and this information was plotted in the network to characterize the dominant grouping activities (Fig. 3). While palm acted as a strong networking activity, coffee was represented by the leaders of two of the three coffee groups of the ejido, a feature shared by the authority's network represented only by the Comisariado ejidal. The general network included the peripheral actors excluded from other productive networks and one of the founders of the ejido, who was also the node with the highest betweenness in the global network.

\section{Coffee groups network analysis}

While palm and ecotourism have each remained under a single group, coffee has changed in number and composition of groups during the last decade. We used network analysis to understand social evolution around coffee activities. Organized coffee producers enjoy some advantages, notably transport facilities, support for organic certification schemes, and better prices (Table 2). 
Fig. 3. Sociogram of individuals assigned to the network with the highest indegree. Node size is proportional to indegree.

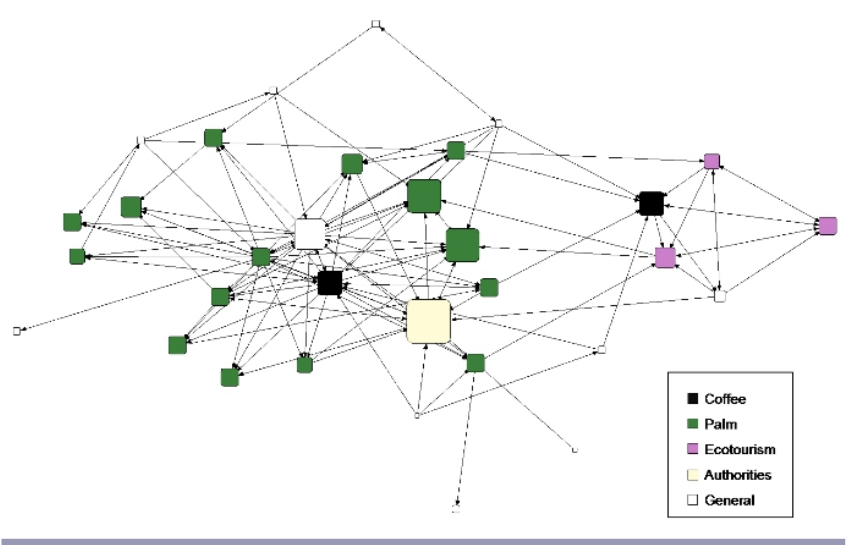

Table 2. Average selling prices for organized and individual ejido's coffee producers. Based on our fieldwork data. Prices are in Mexican pesos per kilo.

\begin{tabular}{llll}
\hline \hline & 2007 & 2008 & 2010 \\
\hline Organized sellers & 21.4 & 23.4 & 32.6 \\
Individual sellers & 18.1 & 21.0 & 27.0 \\
\hline
\end{tabular}

Figure 4 illustrates the changes in coffee groups and the people involved in them. At the start of 2000 (Fig. 4a, black ties) there was a single group, while the rest of the ejido sold the coffee individually. Existing tensions among members of the group led to a split in 2004 (Fig. 4b, black and green ties). In 2008, some people, mostly peripheral members, created a third group (Fig. 4c, pink ties). Some members of the first and second groups, along with the entirety of the third group, started a new group open to all ejido members, both ejidatarios and pobladores, in 2010 (Fig. 4d, orange ties). Finally, in 2011, this group reached 24 people, including all the former members of the second group (Fig. 4e).

Different dynamics influenced the creation of the groups. The 2004 new group was formed, with help from Conservation International, around some members of the palm cooperative that had been created four years earlier and enjoyed support from Conservation International. The third group was established by people not belonging to any of the two existing groups, who looked for the advantages of being organized. The last group represents a major organizational shift based on the idea of creating a local coffee brand by taking advantage of the environmental prestige of the place. This idea was fostered by environmental institutions working in the area, mainly CONANP, the National Commission for Protected Areas.
The use of nonparametric tests allowed us to assess differences in group integration according to land tenure and income (Table 3). Fisher's small samples exact test was used to compare ejidatarios and pobladores. The differences were not statistically significant at $p<0.10$, although the initial group was an ejidatarios-only group, whose relatively small size did not allow it to reach the level of statistical significance.

The Fisher Freeman Halton extension of the Fisher test was used to analyze income differences. The 2000 and 2004 groups showed a significant predominance of the richer members of the community. The creation of the third and fourth groups facilitated the entrance of poorer members, which resulted in a lack of income-related statistical significance of group composition.

Table 3. Statistical tests for land tenure and income terciles in coffee groups; n.s.= not statistically significant.

\begin{tabular}{lcc}
\hline \hline & $\begin{array}{c}\text { Tenure status } \\
\text { (Fisher test) }\end{array}$ & $\begin{array}{c}\text { Income } \\
\text { (Fisher Freeman Halton) }\end{array}$ \\
\hline Coffee Groups 2000 & n.s. & High Income $(p=0.002)$ \\
Coffee Groups 2004 & n.s. & High Income $(p=0.046)$ \\
Coffee Groups 2008 & n.s. & n.s. \\
Coffee Groups 2010 & n.s. & n.s. \\
Coffee Groups 2011 & n.s. & n.s. \\
\hline
\end{tabular}

\section{DISCUSSION}

\section{Community network structure}

Sierra Morena, like many other ejidos in Mexico, is not a uniform community (Barnes 2009). The results show the existence of centrality in the network (Borgatti and Everett 1999), where richer ejidatarios_-being mentioned significantly more frequently by other nodes-tend to occupy core positions. High indegree ejidatarios-frequently sought people - act as focal points, depicting a hierarchical structure (confirmed by the Krackhardt test) where its network position is an indicator of the acquired social status (Snijders 2010), which in this case relates to land tenure rights and income. The relationship between economic assets and network centrality has been demonstrated in other places $(\mathrm{Wu}$ and Pretty 2004).

Ejidos, as other theoretically horizontal structures, are not free from power asymmetries (Whitehead and Tsikata 2003, Peters 2004). Centralized structures are related to group efficiency in problem solving (Freeman 1978, Bonacich 1987), and they can be optimal in the initial phases of any institution or in times of change (Bodin et al. 2006, Janssen et al. 2006). In this case, some central actors have been crucial in the community because they are the ones that have historically fostered connections with outside institutions, one of the key factors in understanding the successful development of the ejido. This has been similarly reported in other contexts (King 2000). 
Fig. 4. Evolution of coffee groups, 2000-2011.

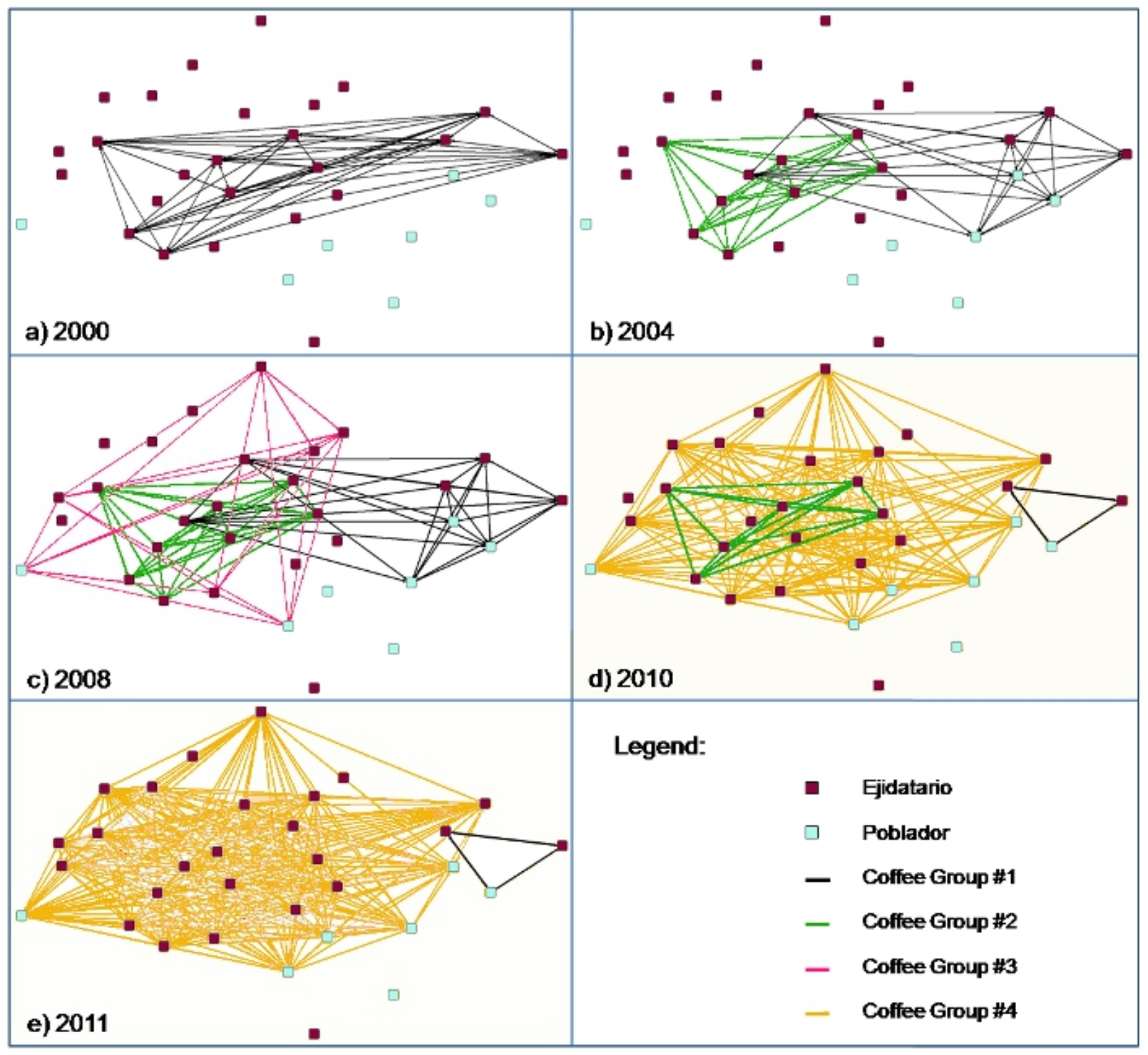

By introducing innovations like the first coffee or palm cultivated plots, core actors have acted as bridges (bringing information from outside) and hubs (disseminating it). This confirms Bodin and Crona's (2009) hypotheses about the potential positive effect of core actors "with regard the adoption of new, more sustainable farming techniques and agricultural output at the village level" that "could be beneficial for other forms of communication value to resource governance in the future" (Bodin and Crona 2009:371).

Innovations represent a process of collective learning consisting of information transmission and deliberation (Schusler et al. 2003, Newig et al. 2010). Core actors have been key for the social learning process of Sierra Morena.
However, other actors have also intervened since the ejido's structures facilitate deliberation, and regulations must be discussed and approved within the assembly.

At the same time, our study also reflects the classical problems derived from centralized structures. Gains in collective action can be outweighed by the exclusion of actors from decisionmaking (Ernstson et al. 2008). This happened when Sierra Morena's collective working broke down in the 1980s due to leadership problems, a typical tendency in Mexican ejidos that usually parcel land after initially working in unity (Haenn 2006). Informal conversations about that period in Sierra Morena confirm that although the collective economy brought good levels of livelihood and equity, the rupture eventually 
occurred due to the exclusion of people in decision-making. Collective working seems to have been reinforced while the land was being defended, as there was a clear and common purpose. Once achieved, however, rivalries easily emerged.

The five-node subgroup is evidence of these rivalries which have dominated the community since then. Their members did not enter the palm cooperative due to problems with palm leaders, and they preferred to start ecotourism activities on their own. While subgroups bring heterogeneity to the network, they can also prompt "us and them" attitudes, thereby hindering collective action (Borgatti and Foster 2003, Smith 2011).

\section{Productive networks structure}

Global processes such as market integration alter livelihoods and social relationships (Ruiz Pérez et al. 2004, Godoy et al. 2007) because they require investments in new productive structures that are adapted to different market demands. For example, productive organizations such as common forest enterprises are regarded as new ways of generating social capital motivated by external factors that can lead to positive outcomes in environmental governance (Antinori and Bray 2005). Our results show that after the breakdown of the ejido in individual plots, different livelihood activities have been the source of new networks. Coffee, the main income source, generates the largest network. Its transitivity is low because it is a commercialization network organized around a few coffee leaders that acts once a year around the coffee harvest period. Thus, it does not confer a strong group feeling.

The palm network is more transitive than that of the coffee in spite of having a comparable size. Because palm is a protected species, palm harvesting and commercialization are strongly regulated. Transitivity, a measure of clustering, implies cohesiveness, reciprocity, and fast communication inside the group. Unlike the coffee market, the palm market is a monopsony that works on a weekly basis. Thus, it requires more planning and coordination (Rico García-Amado et al. unpublished manuscript). A community enterprise-a cooperative in this case-suits these requirements better (Antinori and Bray 2005). This leads to strong and frequent interactions, which results in a tighter structure with highly united members. Although ejidatarios from the high income tercile predominate in the cooperative, it is also open to new members under strict entering conditions (commitment to plant 5 ha of palm, invest some money, and meet weekly palm deliveries), which has resulted in its recent expansion and incorporation of pobladores. As of December 2011, the palm cooperative consisted of 21 members.

Ecotourism, a small network in the ejido, was proposed by CONANP to diversify income options in the community. However, the area is off the main tourist routes, and ecotourism does not provide a stable source of income, as opposed to other places where it is displacing traditional activities (García-
Frapolli et al. 2008, Gutierrez Rodriguez et al. 2011). Hence, ecotourism in Sierra Morena is an inferior opportunity carried out by people from the low income tercile. The ecotourism network has the highest transitivity, a normal fact given its small size. It constitutes, together with one more person, a distinct subgroup in the cluster analysis, thereby suggesting a close structure.

Our study shows that market requirements, further than shaping livelihood strategies, also shape different types of networks. The palm network is dense and selective, while coffee is lax and inclusive; they form two different and yet complementary networks that are adapted to their respective market requirements. Both networks can strengthen each other because they occupy two different market niches. Ecotourism can be complementary to coffee as well, but not to palm.

Transitivity can also be understood as an indicator of bond strength, as tight bonds are expected to be more transitive (Granovetter 1973, 1983, Weimann 1983). Thus, a more transitive network like palm is a source of bonding ties that reinforce the division within the community, while coffee offers bridging ties that can potentially unite the whole ejido. While bonding ties-strong connections inside groupsprovide trust relationships, bridging ties-weak inter-groups connections-give access to new opportunities, thereby increasing diversity and resilience (Borgatti and Foster 2003, Newman and Dale 2005, 2007). The general, all-purpose network can also act as a bridging link, particularly for those outside any other activity.

The creation of a unique and solid coffee group has increased the bridging ties that have contributed to the recovery of collective action after the individualization of the ejido. These links might evolve to bonding ties in the case of establishing a local coffee brand, as it may produce a denser and more transitive network due to increased planning and bureaucracy, similar to that of the palm cooperative.

The evolution of coffee groups has followed a classical adoption curve (Feder et al. 1985) where the wealthier integrated the first group, with most members of the ejido eventually joining in the last group. Coffee group establishment has been facilitated by the economic advantages the groups offer to farmers. But it was the existence of an original commons - the ejido- that prompted the emergence and reorganization of groups, especially for the poorer members, as prior experiences enhance the ability to agree upon rules (Ostrom 2000).

\section{Building up social capital}

The institutional setting of the ejido facilitates the building of social capital. It allows ties formation with face-to-face communications, and thus increases the potential for trust and reduces transaction costs (Pretty 2003). It also forces people to agree on common regulations and enforcement, including 
community work (Gibson et al. 2005). And, as shown in this case, the ejido fosters the emergence of bridging bonds, which are important in order to achieve collective action (Newman and Dale 2005, Bodin et al. 2006).

These properties do not automatically shape the ejido as a horizontal, non-conflictive, and fair structure. The SNA in Sierra Morena has shown inequalities, distrust, and internal disputes, as other studies on the subject have also demonstrated (Agarwal 2001, Cleaver 2005). Still, they have achieved collective action that has led to positive outcomes on natural resource management. The common knowledge (to use Chwe's [1999] terminology) making it possible has been the strong consensus on the benefits of conservation: stable sources of income through organic markets, environmental quality of the place, and international prestige (Rico GarcíaAmado et al. 2011).

The ejido's structure has provided the basis for farmers' organization in the organic market, permitting advancement in the value chain and improving their livelihoods, even for poorer members. Thus, the ejido, although harboring landless people and income differences (Taylor and Zabin 2000, Barnes 2009), can also be a buffer for inequalities, as it provides more opportunities for the landless than other types of properties (Bray et al. 2006, Rico García-Amado et al. 2011).

Authority rotation in Sierra Morena has helped disseminate power and build temporary bridging ties. This has led to a changing network and an increase in redundancy and has helped build resilience (Bodin et al. 2006). In this case, the current Comisariado, a young person from the middle income tercile, has the highest indegree. The authority's network is also a source of ties with outside institutions. Links with other ejidos, government institutions, environmental nongovernmental organizations, or international agents usually channeled through the Comisariado, have been crucial for the successful natural resource management in Sierra Morena, as they have helped in fostering common knowledge. Similarly, nonconflictive founding figures as the focal point of the general, all-purpose network act as an inclusive and social smoothing factor in the community.

Common knowledge is usually sown by dominant groups (Ishihara and Pascual 2009). However, its ability to generate bridging interactions and give some recognition and benefits to marginalized groups has helped accomplish a positive institutional outcome in Sierra Morena, in line with results shown in other places (Taylor 1994, Newell et al. 2004).

\section{CONCLUSION}

We have used social networks to analyze a rural community with a successful management of common pool natural resources. The network resembles a hierarchical structure, with the better off tending to be in the center, while the landless occupy peripheral positions. Although this has helped organize productive activities in the ejido, it has also been the source of internal conflicts.

Market requirements shape productive networks. Commercialization groups, like those for coffee, generate bridging ties, while productive enterprises, like the palm cooperative, are a source of bonding ties. Thus, different activities form diverse and complementary networks.

Our study indicates that despite power asymmetries and internal conflicts, the ejido facilitates an effective management of common pool resources but does not guarantee its long term success. Hence, there is a need to actively work on the institutional model (Klooster 2000) to ensure that the network can be decentralized and efficient because "highly centralized networks may not be appropriate for governing socialecological systems over time" (Bodin and Crona 2009:371). Reinforcing participatory education, higher transparency, and better integration of the excluded population (Agarwal 2000, Adams et al. 2003) could go in this direction.

Responses to this article can be read online at: http://www.ecologyandsociety.org/vol17/iss3/art3/responses/

\section{Acknowledgments:}

We would like to thank CONANP staff, José Luis Molina and Sonia Hernández, for their useful help. The research has been partially funded by the Spanish Cooperation Agency (AECID).

\section{LITERATURE CITED}

Acheson, J. M. 2006. Institutional failure in resource management. Annual Review of Anthropology 35:117-134. http://dx.doi.org/10.1146/annurev.anthro.35.081705.123238

Adams, W. M., D. Brockington, J. Dyson, and B. Vira. 2003. Managing tragedies: understanding conflict over common pool resources. Science 302:1915-1916. http://dx.doi.org/10. 1126/science. 1087771

Agarwal, B. 2000. Conceptualising environmental collective action: why gender matters. Cambridge Journal of Economics 24:283-310. http://dx.doi.org/10.1093/cje/24.3.283

Agarwal, B. 2001. Participatory exclusions, community forestry, and gender: an analysis for South Asia and a conceptual framework. World Development 29:1623-1648. http://dx.doi.org/10.1016/S0305-750X(01)00066-3

Agrawal, A. 2001. Common property institutions and sustainable governance of resources. World Development 29:1649-1672. http://dx.doi.org/10.1016/S0305-750X(01)00063-8 
Agrawal, A., and E Ostrom. 2001. Collective action, property rights, and decentralization in resource use in India and Nepal. Politics \& Society 29:485-514. http://dx.doi.org/10.1177/003 $\underline{2329201029004002}$

Antinori, C., and D. Bray. 2005. Community forest enterprises as entrepreneurial firms: economic and institutional perspectives from Mexico. World Development 33:15291543. http://dx.doi.org/10.1016/j.worlddev.2004.10.011

Ballet, J., N. Sirven, and M. Requiers-Desjardins. 2007. Social capital and natural resource management: a critical perspective. The Journal of Environment \& Development 16:355-374. http://dx.doi.org/10.1177/1070496507310740

Barnes, G. 2009. The evolution and resilience of communitybased land tenure in rural Mexico. Land Use Policy 26:393400. http://dx.doi.org/10.1016/j.landusepol.2008.05.007

Berkes, F. 2004. Rethinking community-based conservation. Conservation Biology 18:621-630. http://dx.doi.org/10.1111/ j.1523-1739.2004.00077.x

Bobrow-Strain, A. 2004. (Dis) Accords: the politics of marketassisted land reforms in Chiapas, Mexico. World Development 32:887-903. http://dx.doi.org/http://dx.doi.org/10.1016/j.wor lddev.2004.01.007

Bodin, Ö., and B. I. Crona. 2009. The role of social networks in natural resource governance: what relational patterns make a difference? Global Environmental Change 19:366-374. htt p://dx.doi.org/http://dx.doi.org/10.1016/j.gloenvcha.2009.05.002

Bodin, Ö., B. Crona, and H. Ernstson. 2006. Social networks in natural resource management: What is there to learn from a structural perspective? Ecology and Society 11(2):r2. [online] URL: http://www.ecologyandsociety.org/vol11/iss2/ resp2/

Bodin, Ö., and C. Prell. 2011. Social networks and natural resource management: uncovering the social fabric of environmental governance. Cambridge University Press, Cambridge, UK.

Bonacich, P. 1987. Power and centrality: a family of measures. American Journal of Sociology 92:1170-1182. http://dx.doi.o rg/http://dx.doi.org/10.1086/228631

Borgatti, S. P., and M. G. Everett. 1999. Models of core/ periphery structures. Social Networks 21:375-395. http://dx.d oi.org/http://dx.doi.org/10.1016/S0378-8733(99)00019-2

Borgatti, S., and P. Foster. 2003. The network paradigm in organizational research: a review and typology. Journal of Management 29:991-1013.

Bray, D. B., C. Antinori, and J. M. Torres-Rojo. 2006. The Mexican model of community forest management: the role of agrarian policy, forest policy and entrepreneurial organization. Forest Policy and Economics 8:470-484. http://dx.doi.org/ht tp://dx.doi.org/10.1016/j.forpol.2005.08.002

Bray, D. B., L. Merino-Perez, and D. Barry. 2005. The community forests of Mexico. University of Texas Press, Austin, Texas, USA.

Charnley, S., and M. R. Poe. 2007. Community forestry in theory and practice: Where are we now? Annual Review of Anthropology 36:301-336. http://dx.doi.org/http://dx.doi.org/ 10.1146/annurev.anthro.35.081705.123143

Chwe, M. S. Y. 1999. Structure and strategy in collective action. American Journal of Sociology 105:128-156. http://d x.doi.org/10.1086/210269

Cleaver, F. 2000. Moral ecological rationality, institutions and the management of common property resources. Development and Change 31:361-383. http://dx.doi.org/10.1111/1467-766 $\underline{0.00158}$

Cleaver, F. 2005. The inequality of social capital and the reproduction of chronic poverty. World Development 33:893906. http://dx.doi.org/10.1016/j.worlddev.2004.09.015

Cornelius, W., and D. Myhre. 1998. The transformation of rural Mexico: reforming the ejido sector. Center for USMexican Studies, University Of California, San Diego, California, USA.

Crona, B., and Ö. Bodin. 2006. What you know is who you know? Communication patterns among resource users as a prerequisite for co-management. Ecology and Society 11(2):7. [online] URL:http://www.ecologyandsociety.org/voll1/iss2/art7/

Crona, B., and K. Hubacek. 2010. The right connections: How do social networks lubricate the machinery of natural resource governance? Ecology and Society 15(4):18. [online] URL: http://www.ecologyandsociety.org/vol15/iss4/art18/

Dietz, T., E. Ostrom, and P. C. Stern. 2003. The struggle to govern the commons. Science 302:1907-1912. http://dx.doi.o $\mathrm{rg} / 10.1126 /$ science.1091015

Downey, S. S. 2010. Can properties of labor-exchange networks explain the resilience of swidden agriculture? Ecology and Society 15(4):15.

[online] URL:http://www.ecologyandsociety.org/vol15/iss4/art15/

Ernstson, H., S. Sörlin, and T. Elmqvist. 2008. Social movements and ecosystem services-the role of social network structure in protecting and managing urban green areas in Stockholm. Ecology and Society 13(2):39. [online] URL:http://www.ecologyandsociety.org/vol13/iss2/art39/ 
Ezzine de Blas, D., M. Ruiz-Pérez, and C. Vermeulen. 2011. Management conflicts in Cameroonian community forests. Ecology and Society 16(1):8. [online] URL:http://www.ecolo gyandsociety.org/vol16/iss1/art8

Feder, G., R. E. Just, and D. Zilberman. 1985. Adoption of agricultural innovations in developing countries: a survey. Economic Development and Cultural Change 33:255-298. http://dx.doi.org/10.1086/451461

Feeny, D., F. Berkes, B. J. McCay, and J. M. Acheson. 1990. The tragedy of the commons: twenty-two years later. Human Ecology18:1-19. http://dx.doi.org/10.1007/BF00889070

Folke, C., T. Hahn, P. Olsson, and J. Norberg. 2005. Adaptive governance of social-ecological systems. Annual Review of Environment and Resources 30:441-473. http://dx.doi.org/10 .1146/annurev.energy.30.050504.144511

Freeman, L. C. 1978. Centrality in social networks conceptual clarification. Social Networks 1:215-239. http://dx.doi.org/10 $.1016 / 0378-8733(78) 90021-7$

García-Frapolli, E., V. M. Toledo, and J. Martinez-Alier. 2008. Adaptations of a Yucatec Maya multiple-use ecological management strategy to ecotourism. Ecology and Society 13 (2):31. [online] URL:http://www.ecologyandsociety.org/vol13/ iss $2 / \operatorname{art} 31 /$

Gibson, C. C., J. T. Williams, and E. Ostrom. 2005. Local enforcement and better forests. World Development 33:273284. http://dx.doi.org/10.1016/j.worlddev.2004.07.013

Gilmour, D., and B. Fisher. 2011. FAO forestry paper 165. Reforming forest tenure. Issues, principles and process. FAO, Rome, Italy.

Girvan, M., and M. E. J. Newman. 2002. Community structure in social and biological networks. Proceedings of the National Academy of Sciences of the United States of America 99:78217826. http://dx.doi.org/10.1073/pnas.122653799

Godoy, R., V. Reyes-García, T. Huanca, W. R. Leonard, R. G. Olvera, J. Bauchet, Z. Ma, J. John, M. Miodowski, O. Z. Rios, V. Vadez, and C. Seyfreid. 2007. The role of community and individuals in the formation of social capital. Human Ecology 35:709-721. http://dx.doi.org/10.1007/s10745-006-9106-1

Gould, R. V. 1993. Collective action and network structure. American Sociological Review 58:182-196. http://dx.doi.org $\underline{110.2307 / 2095965}$

Granovetter, M. S. 1973. The strength of weak ties. American Journal of Sociology 78:1360-1380. http://dx.doi.org/10.108 $\underline{6 / 225469}$

Granovetter, M. 1983. The strength of weak ties: a network theory revisited. Sociological Theory 1:201-233. http://dx.doi. org/10.2307/202051
Gutierrez Rodriguez, L., M. Ruiz Perez, X. Yang, and Geriletu. 2011. From farm to rural hostel: new opportunities and challenges associated with tourism expansion in Daxi, a village in Anji County, Zhejiang, China. Sustainability 3:306321. http://dx.doi.org/10.3390/su3010306

Haenn, N. 2006. The changing and enduring ejido: a state and regional examination of Mexico's land tenure counterreforms. Land Use Policy 23:136-146. http://dx.doi.org/10.1 016/j.landusepol.2004.07.002

Hanneman, R. A., and M. Riddle. 2005. Introduction to social network methods. University of California, Riverside, California, USA.

Harriss, J. 2002. Depoliticizing development: the World Bank and social capital. Anthem Press, London, UK.

Heckathorn, D. D. 1996. The dynamics and dilemmas of collective action. American Sociological Review 61:250-277. http://dx.doi.org/10.2307/2096334

Ishihara, H., and U. Pascual. 2009. Social capital in community level environmental governance: a critique. Ecological Economics 68:1549-1562. http://dx.doi.org/10.1016/j.ecolec on.2008.11.003

Instituto Nacional de Estadística y Geografía (INEGI). 2007. Censo Ejidal 2007. [online] URL: http://www.inegi.org.mx/est/ contenidos/proyectos/Agro/ca2007/Resultados_Ejidal/default. aspx

Janssen, M. A., Ö. Bodin, J. M. Anderies, T. Elmqvist, H. Ernstson, R. R. J. McAllister, P. Olsson, and P. Ryan. 2006. Toward a network perspective of the study of resilience in social-ecological systems. Ecology and Society 11(1):15. [online] URL:http://www.ecologyandsociety.org/vol11/iss1/art15/

King, A. 2000. Managing without institutions: the role of communication networks in governing resource access and control. Dissertation. University of Warwick, Coventry, UK. [online] URL: http://wrap.warwick.ac.uk/36402/1/WRAP_TH ESIS_King_2000.pdf

Klooster, D. 2000. Institutional choice, community, and struggle: a case study of forest co-management in Mexico. World Development 28:1-20. http://dx.doi.org/10.1016/S030 $\underline{\text { 5-750X(99)00108-4 }}$

Klooster, D. 2003. Campesinos and Mexican forest policy during the twentieth century. Latin American Research Review 38:94-126. http://dx.doi.org/10.1353/lar.2003.0018

Klooster, D., and O. Masera. 2000. Community forest management in Mexico: carbon mitigation and biodiversity conservation through rural development. Global Environmental Change 10:259-272. http://dx.doi.org/10.1016/S0959-3780(00) $\underline{00033-9}$ 
Krackhardt, D. 1994. Graph theoretical dimensions of informal organizations. Pages 89-111 in K. Carley and M. Prietula, editors. Computational organizational theory. Lawrence Erlbaum Associates, Hillsdale, New Jersey, USA.

Lehtonen, M. 2004. The environmental-social interface of sustainable development: capabilities, social capital, institutions. Ecological Economics 49:199-214. http://dx.doi. org/10.1016/j.ecolecon.2004.03.019

Moguel, P., and V. M. Toledo. 1999. Biodiversity conservation in traditional coffee systems of Mexico. Conservation Biology 3:11-21. http://dx.doi.org/10.1046/j.15 23-1739.1999.97153.x

Newell, S., C. Tansley, and J. Huang. 2004. Social capital and knowledge integration in an ERP project team: the importance of bridging and bonding. British Journal of Management 15:43-57. http://dx.doi.org/10.1111/j.1467-8551.2004.00405. $\underline{x}$

Newig, J., D. Günther, and C. Pahl-Wostl. 2010. Synapses in the network: learning in governance networks in the context of environmental management. Ecology and Society 15(4)24. [online] URL:http://www.ecologyandsociety.org/vol15/iss4/art24/

Newman, L., and A. Dale. 2005. Network structure, diversity, and proactive resilience building: a response to Tompkins and Adger. Ecology and Society 10(1):r2. [online] URL:http://ww w.ecologyandsociety.org/vol10/iss 1/resp2/

Newman, L., and A. Dale. 2007. Homophily and agency: creating effective sustainable development networks. Environment, Development and Sustainability 9:79-90. http:/ /dx.doi.org/10.1007/s10668-005-9004-5

Ostrom, E. 1990. Governing the commons. Cambridge University Press, Cambridge, UK.

Ostrom, E. 1994. Constituting social capital and collective action. Journal of Theoretical Politics 6:527-562. http://dx.d oi.org/10.1177/0951692894006004006

Ostrom, E. 2000. Collective action and the evolution of social norms. Journal of Economic Perspectives 14:137-158. http:// dx.doi.org/10.1257/jep.14.3.137

Peters, P. E. 2004. Inequality and social conflict over land in Africa. Journal of Agrarian Change 4:269-314. http://dx.doi. org/10.1111/j.1471-0366.2004.00080.x

Portes, A. 2000. The two meanings of social capital. Sociological Forum 15:1-12.

Portes, A., and P. Landolt. 2000. Social capital: promise and pitfalls of its role in development. Journal of Latin American Studies 32:529-547. http://dx.doi.org/10.1017/S0022216X00 $\underline{005836}$
Prell, C., K. Hubacek, and M. S. Reed. 2008. Stakeholder analysis and social network analysis in natural resource management. Society and Natural Resources 22:501-518. http://dx.doi.org/10.1080/08941920802199202

Pretty, J. 2003. Social capital and the collective management of resources. Science 302:1912-1914. http://dx.doi.org/10.1126/ science. 1090847

Pretty, J., and D. Smith. 2004. Social capital in biodiversity conservation and management. Conservation Biology 18:631-638. http://dx.doi.org/10.1111/j.1523-1739.2004.00126. $\underline{\mathrm{X}}$

Pretty, J., and H. Ward. 2001. Social capital and the environment. World Development 29:209-227. http://dx.doi.o rg/10.1016/S0305-750X(00)00098-X

Putnam, R. D. 2001. Bowling alone: the collapse and revival of American community. Simon and Schuster, New York, USA.

Richards, M. 1997. Common property resource institutions and forest management in Latin America. Development and Change 28:95-117. http://dx.doi.org/10.1111/1467-7660.00036

Rico García-Amado, L., M. Ruiz Pérez, F. Reyes Escutia, S. Barrasa García, and E. Contreras Mejía. 2011. Efficiency of payments for environmental services: equity and additionality in a case study from a biosphere reserve in Chiapas, Mexico. Ecological Economics 70:2361-2368. http://dx.doi.org/10.1016/ j.ecolecon.2011.07.016

Ruiz-Pérez, M., B. Belcher, R. Achdiawan, M. Alexiades, C. Aubertin, J. Caballero, B. Campbell, C. Clement, T. Cunningham, A. Fantini, H. de Foresta, C. García Fernández, K. H. Gautam, P. Hersch Martínez, W. de Jong, K. Kusters, M. G. Kutty, C. López, M. Fu, M. A. Martínez Alfaro, T. R. Nair, O. Ndoye, R. Ocampo, N. Rai, M. Ricker, K. Schreckenberg, S. Shackleton, P. Shanley, T. Sunderland, and Y. Youn. 2004. 2004. Markets drive the specialization strategies of forest peoples. Ecology and Society 9(2):4. [online] URL:http://www.ecologyandsociety.org/vol9/iss2/art4/

Schlager, E., and E. Ostrom. 1992. Property-rights regimes and natural resources: a conceptual analysis. Land Economics 68:249-262. http://dx.doi.org/10.2307/3146375

Schusler, T. M., D. J. Decker, and M. Pfeffer. 2003. Social learning for collaborative natural resource management. Society Natural Resources 16:309-326. http://dx.doi.org/10.1 $\underline{080 / 08941920390178874}$

Siegel, D. A. 2009. Social networks and collective action. American Journal of Political Science 53:122-138. http://dx. doi.org/10.1111/j.1540-5907.2008.00361.x 
Smith, A. 2011. Group composition and conditional cooperation. Journal of Socio-Economics 40:616-622. http:// dx.doi.org/10.1016/j.socec.2011.04.018

Snijders, T. 2010. Statistical models for social networks. Annual Review of Sociology 37:131-153. http://dx.doi.org/10 $\underline{.1146 / \text { annurev.soc.012809.102709 }}$

Van Staveren, I. 2003. Beyond social capital in poverty research. Journal of Economic Issues 37:415-423.

Tacconi, L. 2007. Decentralization, forests and livelihoods: theory and narrative. Global Environmental Change 17:338348. http://dx.doi.org/10.1016/j.gloenvcha.2007.01.002

Taylor, C. 1994. Multiculturalism: examining the politics of recognition. Princeton University Press, Princeton, USA.

Taylor, P. L., and C. Zabin. 2000. Neoliberal reform and sustainable forest management in Quintana Roo, Mexico: rethinking the institutional framework of the Forestry Pilot Plan. Agriculture and Human Values 17:141-156. http://dx.d oi.org/10.1023/A:1007673521264

Toledo, V., B. Ortiz-Espejel, L. Cortés, P. Moguel, and M. Ordoñez. 2003. The multiple use of tropical forests by indigenous peoples in Mexico: a case of adaptive management. Conservation Ecology 7(3):9. [online] URL: http://www.ecologyandsociety.org/vol7/iss3/art9/

Torres, R. 2003. Linkages between tourism and agriculture in Mexico. Annals of Tourism Research 30:546-566. http://dx.d oi.org/10.1016/S0160-7383(02)00103-2

Vatn, A. 2007. Resource regimes and cooperation. Land Use Policy 24:624-632. http://dx.doi.org/10.1016/j.landusepol.20 $\underline{06.06 .002}$

Weimann, G. 1983. The strength of weak conversational ties in the flow of information and influence. Social Networks 5:245-267. http://dx.doi.org/10.1016/0378-8733(83)90027-8

Whitehead, A., and D. Tsikata. 2003. Policy discourses on women's land rights in Sub-Saharan Africa: the implications of the re-turn to the customary. Journal of Agrarian Change 3:67-112. http://dx.doi.org/10.1111/1471-0366.00051

Wilshusen, P. R., S. R. Brechin, P. C. West, and C. L. Fortwangler. 2002. Reinventing a square wheel: critique of a resurgent "protection paradigm" in international biodiversity conservation. Society and Natural Resources 15:17-40. http:/ /dx.doi.org/10.1080/089419202317174002

Woolcock, M. 1998. Social capital and economic development: toward a theoretical synthesis and policy framework. Theory and Society 27:151-208. http://dx.doi.org /10.1023/A:1006884930135
Wu, B., and J. Pretty. 2004. Social connectedness in marginal rural China: the case of farmer innovation circles in Zhidan, north Shaanxi. Agriculture and Human Values 21:81-92. htt p://dx.doi.org/10.1023/B:AHUM.0000014025.47576.72 